\title{
A Socio-Economic Analysis of African Female Street Traders in the Johannesburg CBD
}

\author{
Pinky Lalthapersad-Pillay \\ Department of Economics, UNISA
}

\begin{abstract}
In recent years the informal sector in both less developed countries and in developing countries, including South Africa, has undergone rapid growth. In South Africa, high levels of unemployment and poverty have pushed many of the unemployed into self-employment activities in the informal sector. The informal sector is a highly diversified segment, and street trading is one type of survivalist activity. In South Africa, street trading is conducted mainly by African women, who sell mostly fruits, vegetables and cooked foods. The quintessential feature of informal sector work is its precarious nature, especially as it evades the ambit of social security and labour legislation. This article explores the nature of street trading undertaken in the Johannesburg CBD, characterised by poor working conditions, low income, extremely long hours and overcrowding.
\end{abstract}

JEL J 81, 23

\section{INTRODUCTION}

In many developing and developed countries, the informal sector is increasingly becoming a major contributor to GDP. South Africa is no exception; the informal sector is an important one, given the high levels of unemployment and poverty in the country. However, the informal sector is not a homogenous entity; enterprises differ in respect of size, scope, nature of activities and income-earning potential. Many people operate in the informal sector as hawkers, vendors and subsistence farmers, and tend to generate income way below the poverty line. This article is an attempt to develop a profile of African women street traders in the Johannesburg CBD and to analyse the inherent characteristics of street trading.

\section{Definition of the informal sector}

The informal sector includes all those who work in small, unregistered enterprises, both employers and employees, as well as self-employed persons 
who work in their own family businesses (WIEGO, 2001). Despite such a clear definition, the generation of statistical information on this sector has proved arduous, given its diversity and wide ranging activities. According to Charmes (2000: 3) the salient features of the informal sector include: ease of entry; small scale activity; little capital and equipment; labour-intensive technology; low skills; low level of organisation; and limited or no access to formal credit, organised markets, education and training; services and amenities.

The 1995 White Paper on National Strategy for the Development and Promotion of Small Business in South Africa (as cited in Lund, 1998: 15) identifies four categories of informal sector activities, namely: survivalist; micro enterprises; small enterprises; and medium enterprises. The survivalist sector comprises of street traders and home-based workers.

The view that the informal sector is an avenue for the development of emerging entrepreneurs has been challenged. Many researchers have argued that the informal sector does not comprise of entrepreneurs, but, rather workers (Horn, 1995: 34). Thus the informal sector is not a hive for entrepreneurial activities, and it contains many contradictions, namely:

- $\quad$ Participation in the informal sector is not temporary, and people do not traverse between the formal and informal sectors. Rather, those in the informal sector have nowhere else to ply their skills.

- $\quad$ Its activities are highly survivalist in nature.

- It involves long work hours, low levels of income, no social security and inadequate safety measures, all of which economically marginalise its participants.

- Whilst it does generate income, it cannot obviate poverty and low standards of living (PCR, 1996: 55).

\section{Growth of the informal sector in South Africa}

We begin by examining reasons for the rampant growth of the informal sector. The growth of the informal sector is inextricably tied to the state of the formal labour market. This is especially true in case of South Africa, where high levels of unemployment and an absence of social security, drew many people into the informal sector. The South African labour market witnessed spiralling unemployment in the post-apartheid era due to the restructuring of the public sector and poor economic growth rates. These events provoked considerable job losses during the period 1994-1998, with 284837 jobs being shed in the formal labour market (143 00 in the public sector alone). Thus in 2002, unemployment according to the expanded definition (excluding search activities), stood at 30 per cent (SSA, 2002). These job losses inflicted a heavy toll on African women 
as 140000 female jobs were lost in the service sector, which is a major employer of African women (Bhoorat, 2002: 41). The PCR (1996:49) contends that it is mass unemployment that generates low earnings in the informal sector.

\section{Size of the informal sector}

Recent estimates of informal sector activities indicate that informal sector employment accounts for one half to three-quarters of non-agricultural employment in developing countries. Specifically, in 1998 it comprised 48 per cent of non-agricultural employment in North America; 51 per cent in Latin America; 65 per cent in Asia and 72 per cent in Sub-Saharan Africa. If South Africa is excluded, the figure rises to 78 per cent. Home-based workers and street vendors are two of the main subgroups of the informal workforce. Taken together, they represent an estimated 10 to 25 per cent of the non-agricultural workforce in developing countries, and over 5 per cent of the total workforce in developed countries (WIEGO, 2001).

Determining the actual size of the informal sector in South Africa is problematic; as different definitions have been employed in past surveys, rendering comparisons impossible. There are many estimates of the size of the informal sector. Bhorat (1999: 326) estimates that there were 569000 informal sector participants in 1995. In 1997, the figure stood at 965 669; in1998, it rose to 1.3 million and in 1999, it increased to 1.9 million (SSA, 1998; 1999; 2002). In 2001, it was estimated that there were 1.8 million people in the informal sector (SSA, 2002).

Estimates of the number of street traders are also contestable. Xaba et al. (2002: 45) maintain that in 1998 there were 3.5 million people within the entire survivalist sector. The Community Agency for Social Enquiry (CASE) study of the Johannesburg CBD found that there were 3176 street traders in 1995 (CASE, 1995). The Durban Metropolitan Area (DRA) study estimated there were 19000 street traders in the whole Durban Metropolitan Area in 1997 (DRA study as cited in Lund, 1998: 21). The Johannesburg Metropolitan Council estimated that there were 8000 street traders in the Johannesburg CBD (City of Johannesburg website, 2003).

\section{Characteristics of street trading}

Most self-employment activities in the informal sector are survival strategies that are extremely low-paying. The growth of informal work is epitomised by the activities of street vendors and homeworkers. Globally, street vending is a common activity in which people earn a living by selling an array of goods and services on the street (WIEGO, 2001). Despite the general perception that street 
trading tends to decline as economies develop, research indicates that it is actually on the increase. Street vending has become an inherent part of the urban informal sector, and it is mainly women that operate as street traders. Street vending is sometimes the only occupational option for many poor people and is the only means of earning some income, however low (WIEGO, 2001).

Lund (1998: 21-22) argues that street trading in South Africa differs from that in other African countries, especially in terms of the types of goods traded. Among South African street traders, manufacturing and services are relatively negligible and trade is skewed in favour of fresh produce, clothing, cosmetics and food. In addition, most South African street traders sell produce not produced by themselves. The DRA study (as cited in Lund, 1998: 22) found that only 3 per cent of women were selling goods or food produced by themselves. The study also found that each trader sold a very limited range of goods: seven out of ten of those who sold food or other products were selling fruits and vegetables, or meats and poultry. The CASE study of the Johannesburg CBD in 1995 recorded similar trends, that is, the most common goods sold were: food (41 per cent), fruit and vegetable (37 per cent) and clothing (30 per cent) (CASE, 1995).

Besides a lack of skills, unfavourable dependency burdens, and high levels of unemployment, a crucial reason why African women turn to the informal sector resides in its easy access. Ease of access rests on the fact that not much start-up capital is necessary. Lund (1998: 23) argues that most women can utilize their own money or borrow from relatives. In Nair's study (1996:74), most of the women started their ventures with less than R200. In the Isipingo study, the figure was less than R50 (Mbona, 1997: 37).

The majority of women in the survivalist, or poor end of street trading are independent traders, who work for themselves and rarely employ others. The working conditions of street traders are precarious, as they endure harsh physical environments, limited or no infrastructure, no shelter against the elements, or access to water, sanitation and storage facilities (Lund, 1998: 30).

African women predominate in the informal sector, especially street trading, due to a host of factors. It is a well-documented fact that African women have the lowest activity rates, are the least likely to be employed in formal employment and have low levels of formal education and skills (Bhorat, 2002: 41). The need to survive in the face of long term unemployment, coupled with heavy dependency burdens are factors that may push African women to the informal sector. 


\section{NATURE OF STUDY}

The study was descriptive in nature and aimed to develop a profile of African street traders, focusing on the nature of street trading, the income generated, the living conditions of street traders, their dependency burdens, hours worked and the presence of gender parameters in task allocation. In compliance with this approach, a structured questionnaire was administered to eighty African female street traders in the Johannesburg CBD in August 2002 (see Appendix A). The questionnaire focused primarily on qualitative information, and little quantitative data was sourced. A process of triangulation made it possible to probe issues from an array of perspectives. Since the study was essentially qualitative in nature, a non-probability convenience sampling method was adopted. Once data was collected, it was coded into conceptual categories and themes. The main statistical techniques applied were descriptive statistics (mean, median, standard deviation), frequencies and cross tabulations, using Statistical Package for Social Services (SPSS) and SAS.

\section{Nature of trading activities}

The study focussed only on African women street traders that sold foodstuffs, namely, fruits, vegetables, nuts and cooked foods. The streets of most CBDs in South Africa are speckled with informal traders, sitting in close proximity to each other and selling similar goods at uniform prices. In street trading across the country, the selling of fresh produce is what most people do, most sellers are women and incomes earned are very low (Lund, 1998: 33). The trading activities that these women engage in is the very simplistic act of buying a relatively large quantity of fruit or vegetable (approximately a $10 \mathrm{~kg}$ pack), subdividing it and re-selling it in smaller volumes. The unsold stock is usually kept at the premises of formal traders, who charge a fee of R15 per week for storage.

Street trading appears to be a highly individualistic endeavour, as women purchase supplies individually rather than as part of a larger group. Thus, there was no evidence of networking among women traders. Regarding the frequency at which supplies were bought, 29 per cent of respondents bought supplies daily, 18 per cent bought once a week, 53 per cent bought twice a week. Almost 90 per cent of respondents said they paid in cash for supplies. Of the women selling cooked food, 45 per cent used a gas stove and 55 per cent a paraffin stove to prepare food. The job creation ability of street trading was limited, as only 10 per cent of respondents employed any workers on a part-time basis. 


\section{Age}

In terms of the age distribution of the sample, one-third were under the age of 30 and two-third's over the age of 30. The higher proportion of older women undertaking informal sector work could imply that their lack of skills limits their participation in the formal sector. Thus it can be concluded that women are more likely to start trading when they are older.

\section{Level of education}

In terms of the educational level of respondents, 21 per cent could be regarded as being functionally illiterate (had less than Standard 4 (grade 6)), 34 per cent had completed junior secondary schooling (between Standards 5 and 7 (grades 7 and 9)) and 34 per cent had senior secondary schooling (between Standards 8 and 9 (grades 10 and 11)). Thus, almost 89 per cent of respondents had no matric, a trend that is in keeping with most previous studies that record low levels of education (Lund, 1998; Mbona, 1997). There is a strong link between poor education and participating in the survivalist sector. Cross tabulating age with education shows that younger women traders have more years of education than their older counterparts.

\section{Number, age and status of children}

The majority of women were mothers and whilst one-third of women had 2 children, a quarter had 3 children. Answers to questions on the age distribution of children of women traders indicates that the dependency ratio of these women was quite substantial: 77 per cent of children were under the age of 18 and 28 per cent above 19 years of age. Furthermore, 60 per cent of their children aged over 19 were unemployed, which reaffirms the acuteness of youth unemployment in South Africa (SSA, 1994).

Family living arrangements need to be analysed in terms of whether families remained as intact units or were fragmented, a general practice arising from the past policy of influx control. Almost 52 per cent of respondents had all children living with them, 29 per cent said that all children lived elsewhere, and 19 per cent said some children lived with them and other children lived elsewhere with grandparents. In Bedford's (1995) study, it was mostly children of school going age that were sent to live elsewhere, with 55 per cent of traders endorsing this practice. Factors that contribute to splintered family units could be the lack of adequate housing and the high cost of school fees in urban areas, economic factors that make it impossible for women to sustain the dual responsibilities of earning a living and childcare simultaneously. 
Only 17 per cent of women reported bringing their children to work, either because they did not have anybody to care for their children (9 per cent) or because children helped with selling (9 per cent). The DRA study found that 26 per cent of women looked after their children at their place of work (cited in Lund, 1998: 35).

\section{The status of male partners}

The status of male partners revealed that they either worked full-time (44 per cent), worked part-time ( 9 per cent), were pensioners (14 per cent) or unemployed (33 per cent). The duration of unemployment varied: 15 per cent had been unemployed for less than one year, 46 per cent for between 2 to 5 years and 39 per cent for a period exceeding 5 years. The unemployment patterns of male partners succinctly illustrates the nature of long-term unemployment that South Africa is undergoing. Among the unemployed males, only 10 per cent engaged in piece jobs to earn income. Bhorat (2002) contends that income inequality is worsened by extremely low earnings in the informal sector, coupled with an absence of wage income. This in turn tends to perpetuate intra-household income inequalities and differences in poverty rates.

Only 3 per cent of the unemployed male partners received unemployment benefits, a factor that highlights the limited role of such transfers as a safety net for the poor. In the absence of social security, the practical reality facing families is that the impact of unemployment and poverty can only be cushioned by other family members undertaking additional work. The informal sector remains the only means to gain access to income earning activities.

\section{Accommodation patterns}

Table 1 indicates the nature of accommodation. Only 12 per cent of women were home owners, whilst practices such as renting a room either in a house or flat (35 per cent) and informal settlement occupancy (36 per cent) were common. The mushrooming of informal settlements is due to the shortage of housing that was inherited from the apartheid era and the exclusion of African women from housing in the urban areas. The high proportion of people in informal settlements implies a widespread inability to meet the basic requirements of a minimum standard of living in terms of the provision of shelter. Living conditions in informal settlements are dire, with overcrowding, unhealthy environments and sub-standard infrastructures. Furthermore, the occupancy of old buildings in the city is dangerous, since most of the buildings have been condemned as structurally unfit for occupation. 


\section{Table 1: Place of abode}

\begin{tabular}{|l|c|}
\hline Place of abode & $\mathbf{\%}$ \\
\hline Own house & 12 \\
\hline Rent a room in a house or a flat & 35 \\
\hline Occupy an old building in the city & 9 \\
\hline Rent entire flat in the city & 4 \\
\hline Occupy an outbuilding in a backyard & 2 \\
\hline Live in an informal settlement & 3 \\
\hline Share a house with relatives & 2 \\
\hline
\end{tabular}

Source: Own data

Information on the state of habitation can be gleaned from the number of bedrooms per dwelling. At least 19 per cent of respondents lived in places that had no bedroom, 68 per cent had one bedroom, and 13 per cent had two bedrooms. Inadequate living space forced 75 per cent of all respondents to utilize the lounge as a bedroom. This limited living space has to be set against the fact that the average household consisted of four individuals, and a maximum of nine persons.

The provision of basic services was satisfactory: 67 per cent of respondents had electricity and 63 per cent water-borne sewerage. Some households relied on other forms of energy, for example, gas (2 per cent), paraffin (27 per cent) and coal or wood ( 2 per cent). In terms of teledensity, only 2 per cent of respondents had a telephone.

\section{Migrationary trends}

Respondents were asked about their previous place of residence in order to determine migratory trends. Almost 72 per cent of respondents had migrated to the Gauteng province, which is the wealthiest of all nine provinces in South Africa. It is a well documented fact that urban areas have higher levels of employment and wage levels compared to rural areas (Bhorat, 2002). Respondents rated a number of factors which had influenced their decision to migrate: finding a job (72 per cent); improving their standard of living (51 per cent); availability of better opportunities (23 per cent); availability of better social services like schooling (11 per cent); while 13 per cent said they saw little chance for improvement in their previous residential area. Bhorat et al. (2002: 29) found that moving to an urban area increased the probability of labourmarket participation by 14 per cent and earnings by 18 per cent. 


\section{WORK-RELATED DATA}

Regarding the reasons advanced for working in the informal sector, respondents rated the following options: the need to support family (83 per cent) and the inability to find a job (81 per cent). Other factors included the unemployment of male partners (26 per cent) and the need to earn extra money (10 per cent).

\section{Table 2 Previous occupation}

\begin{tabular}{|l|c|}
\hline Previous occupation & \% \\
\hline Domestic worker in private household & 42 \\
\hline Sales person & 9 \\
\hline Never worked & 26 \\
\hline Machinist & 2 \\
\hline Cashier & 6 \\
\hline Cleaner in factory & 11 \\
\hline Shop assistant & 2 \\
\hline Nursing aid & 2 \\
\hline
\end{tabular}

Source: Own data

Table 2, which lists the type of jobs that women previously undertook, highlights two peculiarities, that is: a high proportion of women (42 per cent) had been domestic workers in private households; and 26 per cent of respondents had never worked. Domestic work tends to be the occupational choice of a large proportion of African women, given their low levels of formal labour market experience and the scarcity of jobs in the labour market. Furthermore, the fact that only 45 per cent of respondents had previously been in full-time employment, 41 per cent in part-time jobs and 13 per cent were casually employed, highlights the preponderance of African women in irregular, secondary sector jobs. An important finding is the movement of women away from domestic work in private households to the informal sector. The presence of a high proportion of individuals who have never been employed complies with the finding by the FAFO Survey that showed that nearly 50 per cent of those looking for work had never worked before (as cited in Bhorat, 2002). These individuals have been denied formal labour market experience and will in future have to be supported to undertake more lucrative and secure alternatives in the informal sector.

Of the women whose previous occupation was domestic worker in private households, 91 per cent were over the age of 30, and 9 per cent under the age of 30. Thus, domestic work did not appear to be popular among younger women. Cross tabulating previous occupations with education shows that 27 per cent of 
domestic workers had less than Standard 4 or grade 6, 36 per cent had between Standards 4 and 7 or grades 6 and 9, whilst 31 per cent had between Standards 8 and 9 or grades 10 and 11. Thus, the fact that women with quite high levels of education had been undertaking domestic work highlights the seriousness of unemployment in the labour market and the extent of poverty at a family level.

Most studies show that people delve in the informal sector out of necessity rather than choice. In the Johannesburg CBD study of 1995, more than 80 per cent said they entered because they were redundant, they had no other skills or they couldn't find another job (CASE, 1995). In Fadane's study (1998: 21), most women had come to Durban from rural areas because of rural poverty and unemployment. South Africa's high rate of landlessness among rural people is a strong push factor towards seeking employment in urban areas.

The work experience of women is such that most of them are far more likely to have never been employed or to have been employed as domestic workers or to start trading when they are widowed. In Nair's study (1996: 58) six out of ten of the women traders had never had a steady job. A study by Pentz study (1992) showed that 85 per cent of the women had either never been employed or had been employed, only as domestic workers.

\section{Household income levels}

Regarding the number of income earners per household, 74 per cent of respondents said they were the main breadwinner. This factor has to be analysed in terms of the number income earners per household and other sources of income accruing to the household. In 57 per cent of households, there were no other income earners besides the respondent; 38 per cent had one other income earner aside from the respondent; 4 per cent had two income earners and 2 per cent had four income earners. These circumstances are consistent with Bhorat's finding that Africans have the greatest likelihood of living in a household with no regular income earners (Bhorat, 2002: 19). In poor households, government transfer payments are a major source of support for the rest of the family. In this study, however, only 12 per cent of households received old age pensions. This could be attributed to the fact that most of the families in urban areas tend to live as nuclear families, as opposed to extended family units in rural areas.

Each respondent supported on average four other people, the maximum being twelve people. The frequency was such that 43 per cent of respondents supported between 1 to 3 other persons; 46 per cent supported between four and six other people and 11 per cent supported between seven and twelve other people. High dependency burdens point to the urgency of government's providing some sort of a safety net for the unemployed. 
The study by Bedford (1995) indicated that three quarters of the members (75 per cent) were the main breadwinners in their households and two thirds of their households had no other earner at all. Thus street vendors are more likely to be household heads, to be the main breadwinner and to have no other earners in the household (Bedford, 1995).

\section{Income levels}

Respondents earned an average of R45 on slack days, ranging from a minimum $\mathrm{R} 2$ to a maximum of R150 per day. The frequency distribution is shown in Figure 1.

Figure 1 Income on slack days

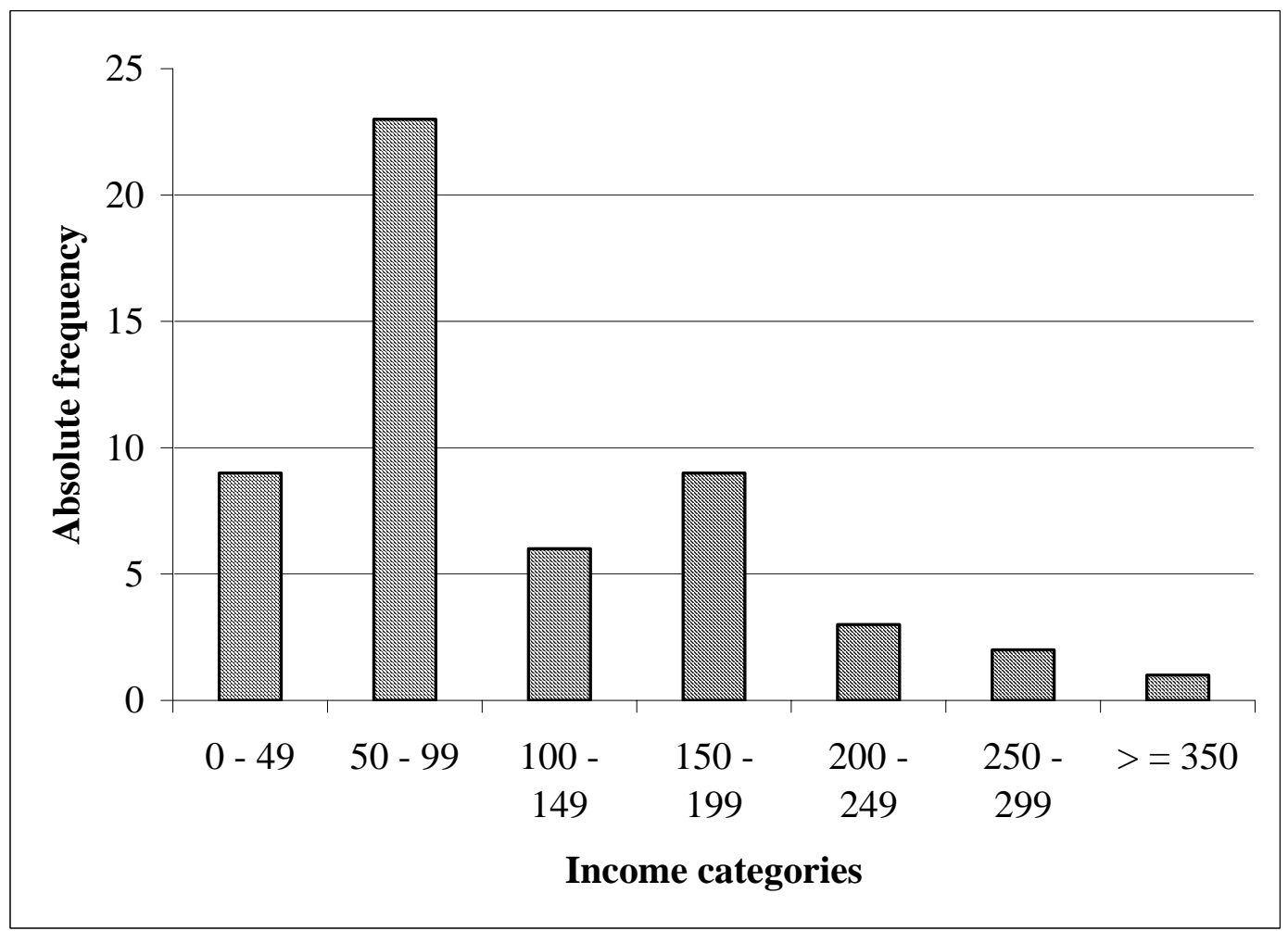

Source: Own data

Respondents were asked how much income they would make if business was good. The average was R99.72, ranging from a minimum of R20 to a maximum of R250 per day. 
Figure 2 Income on good business days

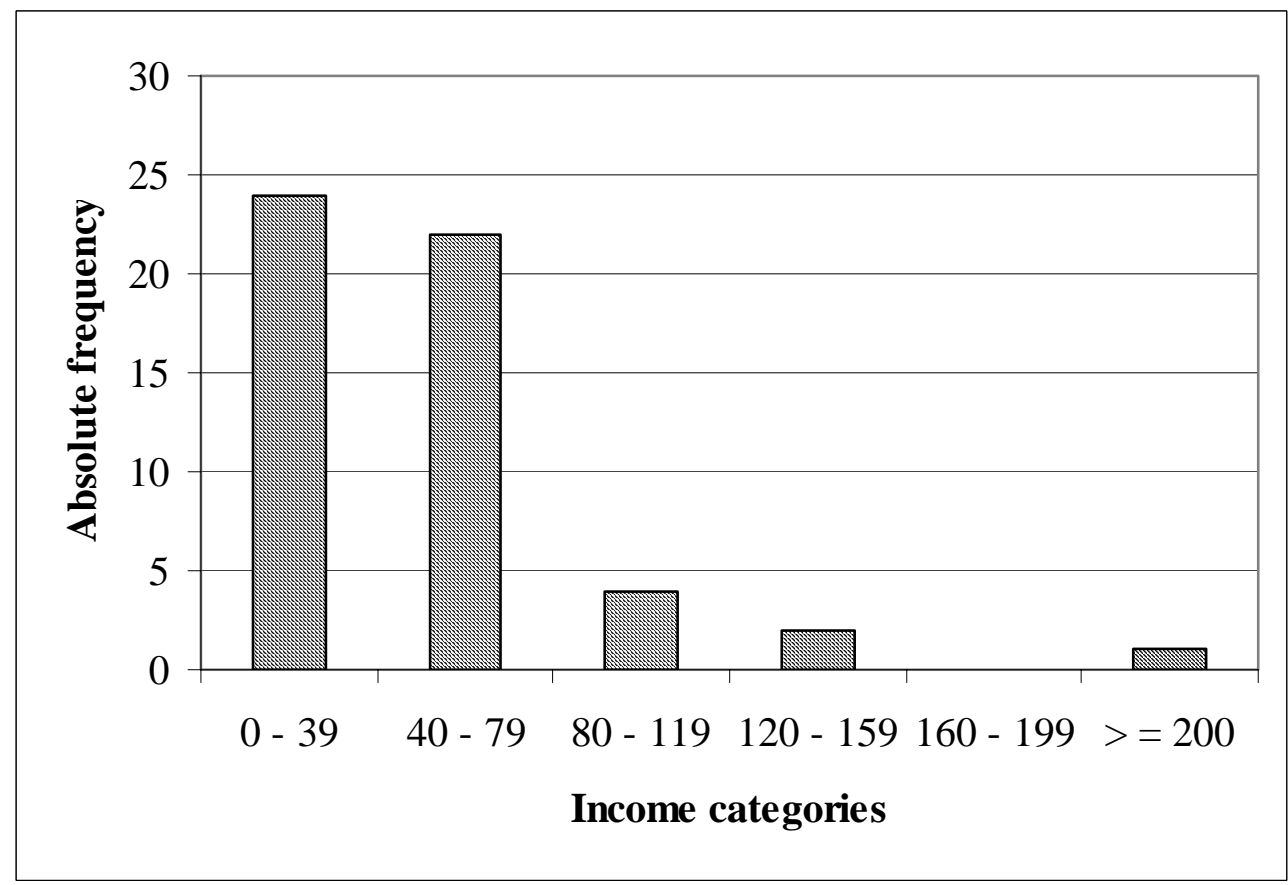

Source: Own data

Respondents were asked what was the total gross income they took home per week, before deducting costs such as supplies, transport and storage fees. The average income taken home was R270.38, ranging from a minimum of R60 to a maximum of R550. Figure 3 shows the frequency distribution.

\section{Figure 3 Total gross income}

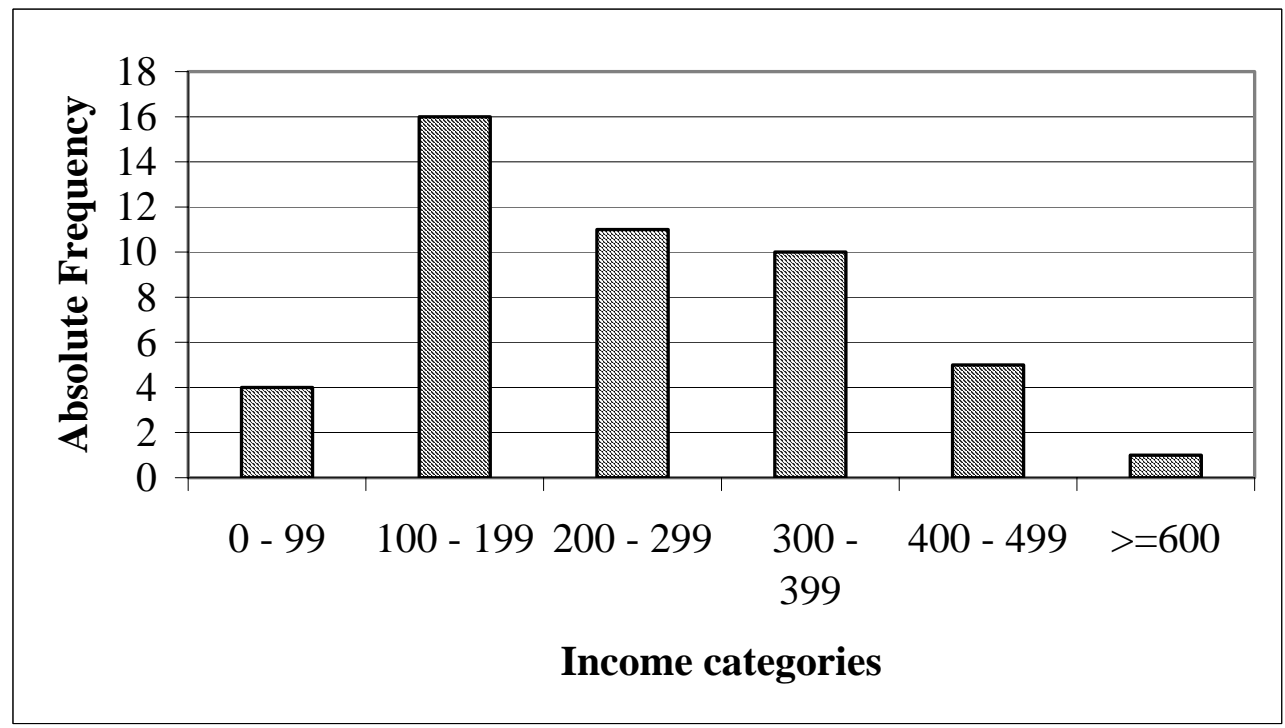

Source: Own data

The above analysis points out that income was very erratic and below the 
Minimum Living Level (MLL) of R950 a month (BMR, 1999). The precariousness of the situation becomes more apparent when one bears in mind that each household supported, on average, four other persons. Compounding the problem was the fact that 28 per cent of women reported that there were days when they did not take home any income. Thus, the absence of regular income is a factor engendering hardship and suffering.

Correlating the number of dependents to the level of income, the study found that 11 per cent of respondents took home between R60 to R100 a week and had an average of 5 dependents; 30 per cent of respondents took home between R120 to R200 a week and had an average of four dependents; 17 per cent of respondents took home between R220 to R250 a week and had an average of 4 dependents; 19 per cent took home between R300 and R380 and had an average of 3 dependents.

An important question is whether higher levels of education are commensurate with high levels of income in the informal sector. There appeared to be a positive correlation between the level of education and the level of income obtained. Those with higher levels of education did take home more income. For example, women with less than Standard 4 took home an average of R238 a week, and those with matric, an average of R458 a week. Thus, education appeared to play an imperative role in terms of the type of goods retailed and the organization of the trading venture.

Most studies show street traders' incomes at well below R600 per month, with an income of lower levels for women. R600 per month was the approximate minimum living level in 1995. In the Johannesburg CBD, 54 per cent of street traders had made up to R600 per month (CASE, 1995: 30).

\section{Work patterns}

Regarding the length of the workday, the average hours worked per day was 10 hours, the minimum being 5 hours and the maximum being 13 hours. The distribution was such that 13 per cent of respondents worked between 5 to 8 hours per day, 60 per cent worked between 9 to 10.5 hours per day and 27 per cent worked between 11 to 13 hours per day. Only 15 per cent worked over the weekend. The work day continued at home in terms of making preparations for the next day's trading. Almost 78 per cent of respondents undertook such preparations, with 42 per cent spending one hour, 30 per cent two hours, 15 per cent three hours, 3 per cent four hours and 2 per cent five hours on such activities. Thus the average hours worked in the informal sector exceeded those in the formal sector. 
Most studies concur that street traders work long and usually regular hours, over all months of the year (Lund, 1998: 34). Most street traders work an average of ten hours a day, except Sunday (CASE, 1995).

In terms of sleep patterns of respondents, the average time that most respondents woke up was 5:20 and went to sleep at 21:05. This analysis explicitly indicates that women's time budgets were overstretched and that working long hours left little time for leisure and rest. This is consistent with most studies that indicate that women in poor households devote much more time to income-generating activities (World Bank, 1990: 31). The considerable effort that women have to put in to earn a little income is indicative of the type of deprivation they have to bear.

\section{Spending patterns}

Only 23 per cent of respondents possessed a savings account at a bank and only 9 per cent belonged to a stokvel or savings club. Stokvels and savings clubs are community-based initiatives that enable groups of women to purposefully save money. Low participation rates in such schemes are tantamount to a low level of social networking among individuals.

Women appeared to have wide control over household decision-making. Women decided how money was spent: namely 62 per cent of respondents said they decided, themselves, on how to spend their income. Most studies on gender allude to the fact that women in poor households devote a greater portion of earned income to the household than men do (World Bank, 1990:36). Regarding the sums of money given to male partners, 28 per cent said that they gave their male partners money for cigarettes, 15 per cent for alcohol, 23 per cent for gambling or Lotto, 6 per cent for supporting children from other marriages and 36 per cent for clothing. This is consistent with the general finding that women contribute a larger portion of their income to the household budget and to financing the expenditure of male partners.

\section{Gender parameters}

Whilst there was no gender bias with respect to the education of children and which children helped with trading activities or household chores, it appears that daughters were saddled with more dual roles and responsibilities. Almost 31 per cent of respondents said that daughters helped in caring for other children, 41 per cent undertook cooking and cleaning and 28 per cent assisted with the next day's preparations. 


\section{Table 3 Division of tasks}

\begin{tabular}{|l|c|}
\hline \multicolumn{1}{|c|}{ Task } & \% \\
\hline Trading activities & 31 \\
\hline Cooking & 19 \\
\hline Cleaning & 19 \\
\hline Seeing to the children & 11 \\
\hline Transporting goods to trading area & 8 \\
\hline Preparations for the next day & 12 \\
\hline
\end{tabular}

Source: Own data

The sexual division of household chores appeared to be rigorous, with males contributing little in this regard. For example, 31 per cent said that their male partners helped in their trading activities, 19 per cent said they helped with the cooking and cleaning, 11 per cent said they helped to look after the children, 8 per cent said they helped to transport goods to the trading location and only 12 per cent said they helped with preparations for the next day's trading. Regarding the execution of household chores, 94 per cent of respondents said they themselves undertook cleaning, 49 per cent cared for the children and 26 per cent helped children with homework. A survey on time use in South Africa in 2001 found that women spent three times as much time on unpaid work (cooking, cleaning and caring for other household members) compared to men (Budlender, et al., 2001: 5). Thus even though women spent an average of ten hours trying to earn income, they could not escape performing household and childcare tasks for the family. This additional unpaid labour in the household makes that the dual burden of these women arduous.

\section{FUTURE RESEARCH NEEDS}

It has to be accepted that street trading comprises a significant portion of the urban informal sector, and is likely to expand rapidly in future, given worsening economic scenarios. However, very little is known about the dynamics of this sector and statistical evidence is clearly lacking. Information is required on a host of variables, for example, the actual number of participants, the sectors wherein they operate, their contribution to GPD and employment, their links to the formal economy and the supply and distribution procedures that they trigger across national borders. Such information will assist policymakers to make informed decisions that will harness and support this often misunderstood entity. 


\section{CONCLUSION}

Whilst it is difficult to formulate an incisive picture of the hardship experienced by women in the informal sector, it is hoped that such information would accentuate the predicament of African women street traders. It is an inescapable fact that growing economic adversity, with the resulting unemployment and poverty, will serve to thrust more people into the informal sector, an area that is already overcrowded. In South Africa, the burden of unemployment falls disproportionately on African women. Informal sector work is no replacement for formal employment. Yet, the practical reality of being unemployed means that if one cannot find a job in the formal labour market, then informal sector work becomes the only alternative, especially for older African women that lack the human capital to gain entry to the formal labour market. However, informal sector work is highly subsistent in nature and offers extremely low levels of income. This is exacerbated by an absence of unemployment benefits for the bulk of the unemployed.

African women in the informal sector display all the manifestations of poverty, not only in terms of low and irregular income, but in terms of the nature of deprivation they have to bear. They have little choice of and access to resources, they endure dismal living standards, an absence of decent housing, overcrowded and unhealthy environments and long work hours.

Moreover, the ability of the informal sector to offer a livelihood to the unemployed will be further constrained by South Africa's huge illegal immigrant population, which also looks to the informal sector as a means of generating income. Thus, overcrowding will drive income levels further down. The economic crisis that South Africa finds itself in can only be addressed by stimulating economic growth, reducing unemployment and inequality, alleviating the plight of the poor and improving living standards.

\section{REFERENCES}

1 BEDFORD, L. (1995) The Self Employed Women's Union Survey: Members and Their Situation, Independent Development Research: Durban.

2 BHORAT, H. (1999) "The October Household Survey and the informal sector - a note," South African Journal of Economics, 67(2): 320-26. 21-38. (2001) "Explaining trends in SA 1993-1998," New Agenda, 4: (2002) "Is a universal income grant the answer," South African Labour Bulletin (SALB), 26(2): 19-24. 
5 BUDLENDER, D., CHOBOKOANE, N. \& MPETTSHENI, Y. (2001) A Survey of Time Use, Statistics South Africa: Pretoria.

6 BUREAU OF MARKET RESEARCH (1999) Minimum and Supplemented Living Levels in the Main and Other Selected Urban Areas of the RSA, UNISA: Pretoria.

7 CHARMES, J. (2000) Gender and Informal Sector, United Nations: New York.

8 COMMUNITY AGENCY FOR SOCIAL ENQUIRY (CASE) (1995) Our Daily Bread: Earning a Living on the Pavements of Johannesburg. Part 2: The Survey, CASE: Johannesburg.

9 FADANE, N. (1998) "Women street vendors in Durban" in Larsson, A., Mapetla, M and Schlyter, A. (eds.) Changing Gender Relations in South Africa, The Institute of Southern African Studies: Roma.

10 HORN, P. (1995) "Self employed women's union - Tackling the classgender intersection,” SALB, 19(6): 34-38.

11 City of Johannesburg Official website (2003) http://www.joburg.org.za/ 2004/jan/jan21-traders.stm.

12 LUND, F. (1998) Women Street Traders in Urban South Africa: A Synthesis of Selected Research Findings, School of Development Studies: Durban.

13 MBONA. D. (1997) Isipingo Street Traders Survey, Report prepared for South Local Council, Durban Metropolitan Area.

14 NAIR, Y. (1996) "Women and survival: trading in crafts and curios at the Durban beachfront”, University of Natal: Masters thesis, Durban.

15 PENTZ, D. (1992) Informal street trading: A case study of Warwick Avenue, University of Natal Masters Thesis, Durban.

16 WORLD DEVELOPMENT REPORT (1990) Poverty, Oxford University Press: Washington.

17 WIEGO (Women in Informal Employment: Globalising and Organising) (2001) “Addressing informality, reducing poverty”, http://www. wiego.org.

18 XABA, J., HORN, P. \& MOTALA, S. (2002) The Informal Sector in sub-Saharan Africa, ILO: Geneva.

\section{RSA Government publications}

President's Council Report (PCR) (1996) Report of the Commission to Investigate the Development of a Comprehensive Labour Market Policy : Restructuring the South African Labour Market. PR 83/1996. Government Printer: Pretoria.

Statistics South Africa (SSA) (1998) October Household Survey (OHS): Pretoria. (1999) OHS: Pretoria. 
(2002) Labour Force Survey: Pretoria.

Dept of Labour (2000) The National Skills Development Strategy, Govt Printer: Pretoria. 


\section{APPENDIX 1}

\section{QUESTIONNAIRE}

\section{A. BIOGRAPHICAL DATA}

1. What is your age?

\begin{tabular}{|l|l|}
\hline Under 19 & \\
\hline Between $20-29$ & \\
\hline Between $30-39$ & \\
\hline Between $40-49$ & \\
\hline Between $50-59$ & \\
\hline Over 60 & \\
\hline
\end{tabular}

2. What is the highest schooling that you completed?

\begin{tabular}{|l|l|}
\hline Less than std 4 & \\
\hline Std 5 to std 7 & \\
\hline Std 8 to 9 & \\
\hline Matric & \\
\hline Matric and Diploma & \\
\hline Degree & \\
\hline
\end{tabular}

3. What is your marital status?

\begin{tabular}{|l|l|}
\hline Never married & \\
\hline Married & \\
\hline Living together & \\
\hline Widowed & \\
\hline Divorced & \\
\hline
\end{tabular}

\section{B. Children}

1. How many children do you have?

2. How many of you children fall in following age categories?

\begin{tabular}{|l|l|}
\hline Under 6 & \\
\hline Between 7 to 11 & \\
\hline Between 12 to 18 & \\
\hline Over 19 & \\
\hline
\end{tabular}

3. With regard to your children, do they?

\begin{tabular}{|l|l|}
\hline All live with you & \\
\hline All live elsewhere with family & \\
\hline Some live with you and some elsewhere & \\
\hline
\end{tabular}

4. How many of your children attend school ? 
5. The children that attend school are they:

\begin{tabular}{|l|l|}
\hline Boys & \\
\hline Girls & \\
\hline Both boys \& girls & \\
\hline
\end{tabular}

6. Do you bring any of your children to work with you?

\begin{tabular}{|l|l|}
\hline Yes & No \\
\hline
\end{tabular}

7. If yes to question 8 , why?

9. Which children help you at this job?

\begin{tabular}{|l|l|}
\hline Boys & \\
\hline Girls & \\
\hline Boys \& girls & \\
\hline
\end{tabular}

10. Are any of your children employed?

11. Do any of your daughters help with the following:

\begin{tabular}{|l|l|}
\hline Looking after the children & \\
\hline Cooking \& cleaning & \\
\hline Preparations for the next day & \\
\hline
\end{tabular}

C. HUSBAND/ PARTNER

1. What does your husband/partner do?

\begin{tabular}{|l|l|}
\hline Has a full-time job & \\
\hline Works part-time & \\
\hline Unemployed & \\
\hline Pensioner & \\
\hline
\end{tabular}

2. If your husband/ partner is unemployed, for how long has he been unemployed? Less than a year

Between 2 to 5 years

Over 5 years

3. Does your husband/ partner collect UIF ?

4. What does your unemployed husband/partner do to earn some income

5. Does you husband/partner help with any of the following activities?

\begin{tabular}{|l|l|}
\hline Your trading activities & \\
\hline Cooking & \\
\hline Cleaning & \\
\hline Seeing to the children & \\
\hline Transporting goods to trading location & \\
\hline Preparations for next day's trading & \\
\hline
\end{tabular}


D. HOUSEHOLD SIZE:

1. Where do you live presently?

\begin{tabular}{|l|l|}
\hline Rent a room in a house or flat & \\
\hline An old building & \\
\hline Flat in the city & \\
\hline Building in a backyard & \\
\hline Informal settlement & \\
\hline Share a house with relatives & \\
\hline
\end{tabular}

2. How long have you been staying at this place?

3 . In which region did you live previously?

\begin{tabular}{|l|l|}
\hline Gauteng & \\
\hline Eastern Cape & \\
\hline Western Cape & \\
\hline Kwa-zulu Natal & \\
\hline Mpumpalanga & \\
\hline Limpopo & \\
\hline Northern Cape & \\
\hline Northern Province & \\
\hline Free State & \\
\hline
\end{tabular}

4. If you lived previously elsewhere, why did you move to Johannesburg?

\begin{tabular}{|l|l|}
\hline To find a job & \\
\hline To improve your standard of living & \\
\hline Saw better opportunities here & \\
\hline Better social services (schooling, housing, health care) & \\
\hline Little chance for improvement in the area you left & \\
\hline
\end{tabular}

5. How many people are there in your household?

6. How many bedrooms do you have?

7. Is the lounge also used as a bedroom?

\begin{tabular}{|l|l|}
\hline Yes & No \\
\hline
\end{tabular}

8. Are any of your parents or in-laws living with you?

9. Do you have any electricity at home?

10. What is your main source or energy at home?

\begin{tabular}{|l|l|}
\hline Gas & \\
\hline Electricity & \\
\hline Paraffin & \\
\hline Coal/wood & \\
\hline
\end{tabular}

11. Do you have water-borne sewerage in your home?

12. Do you own:

\begin{tabular}{|l|l|}
\hline Telkom & \\
\hline Cell phone & \\
\hline
\end{tabular}




\section{E. WORK - RELATED DATA:}

1. Why did you start this venture?

\begin{tabular}{|l|l|}
\hline To support my family & \\
\hline Couldn't find a job & \\
\hline Husband unemployed & \\
\hline To earn extra money & \\
\hline Other - specify & \\
\hline
\end{tabular}

2. In what occupational capacity were you previously employed?

3. Was your previous job a full-time, part-time or casual job?

4. Do you employ any workers?

\begin{tabular}{|l|l|}
\hline Yes & No \\
\hline
\end{tabular}

5. How many people do you have working on:

\begin{tabular}{|l|l|}
\hline Full-time & \\
\hline Part-time & \\
\hline
\end{tabular}

\section{F. HOUSEHOLD INCOME:}

1. Are you the main breadwinner in the household ?

2. How many other people earn income in the household ?

3. How many people depend on your income?

4. Do you parents or in-laws receive a pension?

\section{G. WORK PATTERNS:}

1. At what time do you start working?

2. At what time do you finish working?

3. Do you work over weekends?

5. At what time do you wake up in the morning?

6. At what time do you go to sleep at night?

H. PURCHASING PATTERNS

1. Do you buy your supplies:

\begin{tabular}{|l|l|}
\hline Individually & \\
\hline As part of a group that pools money & \\
\hline
\end{tabular}

2. How often do you buy supplies?

\begin{tabular}{|l|l|}
\hline Daily & \\
\hline Once a week & \\
\hline Twice a week & \\
\hline Once every 2 weeks & \\
\hline
\end{tabular}

3. How do you pay for your supplies?

\begin{tabular}{|l|l|}
\hline Cash & Credit \\
\hline
\end{tabular}

\section{ORGANIZATION OF TRADING VENTURE}

1. What do you use to prepare your food?

\begin{tabular}{|l|l|}
\hline Gas stove & \\
\hline Paraffin & \\
\hline Open fire & \\
\hline
\end{tabular}




\section{J. INCOME DATA}

1. How much income do you make per day when business is good?

2. How much income do you make per day make when business is bad?

3. What is the average income you take home in a week?

4. Are there times when you do not take home any income?

\begin{tabular}{|l|l}
\hline Yes & No \\
\hline
\end{tabular}

K. HOUSEHOLD DYNAMICS:

1. Do you do any of the following when you get home after work:

\begin{tabular}{|l|l|}
\hline Cooking & \\
\hline Cleaning & \\
\hline Seeing to the children & \\
\hline Helping kids with homework & \\
\hline Making preparations for the next day's trading & \\
\hline
\end{tabular}

2. How many hours at night do you spend making such preparations?

\section{SPENDING PATTERNS}

1. Do you have a savings account at a bank?

\begin{tabular}{|l|l|}
\hline Yes & No \\
\hline
\end{tabular}

2. Are you a member of a stokvel?

\begin{tabular}{|l|l|}
\hline Yes & No \\
\hline
\end{tabular}

3. Who decides how to spend the money you make?

\begin{tabular}{|l|l|}
\hline Yourself only & \\
\hline You and your husband/partner & \\
\hline Your husband/partner only & \\
\hline
\end{tabular}

4. Do you give your husband money for any of the following things?

\begin{tabular}{|l|l|}
\hline Cigarettes & \\
\hline Alcohol & \\
\hline Gambling/Lotto & \\
\hline Support children from another marriage & \\
\hline Clothing & \\
\hline
\end{tabular}

